Article

\title{
Different Strokes for Different Folks: Who Votes for Technocratic Parties?
}

\author{
Maria Snegovaya \\ Kellogg Center for Philosophy, Politics, and Economics, Virginia Polytechnic Institute and State University, Blacksburg, \\ VA 24061, USA; E-Mail: marias20@vt.edu
}

Submitted: 15 July 2020 | Accepted: 9 October 2020 | Published: 17 December 2020

\begin{abstract}
In this study, I look at two types of political actors commonly described as 'populist' in literature-namely, rightwing populists and technocratic leaders like France's Emmanuel Macron and the Czech Republic's Andrej Babiš. While both types of political actors tend to emerge as a response to a decline in trust in established parties and adopt platforms with anti-establishment and monist elements, they also possess noticeably different qualities. Unlike rightwing populists, technocrats lack a distinctive ideological profile and tend to adopt more inclusive rhetoric by appealing to a broadlydefined community of people. When contrasted with supporters of rightwing populists, empirical analysis of supporters of Macron's and Babiš' parties shows that the two have few commonalities. Relatively few examples of such political leadership, the lack of a distinct ideological profile and the variation of their support bases suggest that one should use caution when conceptualizing technocratic populists as a distinct theoretical type.
\end{abstract}

\section{Keywords}

nativism; populism; radical right; technocrats

\section{Issue}

This article is part of the issue "Varieties of Technocratic Populism around the World" edited by Petra Guasti (Institute of Sociology of the Czech Academy of Sciences, Czech Republic) and Lenka Buštíková (Institute of Sociology of the Czech Academy of Sciences, Czech Republic / Arizona State University, USA).

(C) 2020 by the author; licensee Cogitatio (Lisbon, Portugal). This article is licensed under a Creative Commons Attribution 4.0 International License (CC BY).

\section{Introduction}

The increase of populist political leaders across the world in the last decade has attracted considerable attention in political science literature (Gidron \& Bonikowski, 2013; Panizza, 2005).

Despite the proliferation of varying types of populist figures, recent studies have primarily paid attention to rightwing populist parties in European countries, including Alternative for Germany, UK Independence Party, and France's National Front (FN, more recently National Rally; Ivaldi, 2018; Schmitt-Beck, 2017; Siri, 2018; Stockemer, 2017). A key defining feature of these parties is an anti-elitist message and the use of a thin-centered populist ideology which views their respective societies as being in a state of constant Manichean struggle between the 'people,' whose interests they claim to represent, and malevolent or corrupt elites (Mudde, 2004, 2007).

In recent years, scholars have also increasingly paid attention to technocratic leaders, who adopt anti- establishment appeals to reject the establishment politics on both sides of the political spectrum, while offering their own technocratic competence and expert solutions to benefit the 'people' (Buštíková \& Guasti, 2019; Havlík, 2019; Heinisch \& Saxonberg, 2017). Studies have referred to the political leadership of Silvio Berlusconi in Italy, Andrej Babiš in the Czech Republic, Emmanuel Macron in France, Donald Trump in the United States, Bidzina Ivanishvili in Georgia, and Rafael Correa in Ecuador as examples of such political actors (Buštíková \& Guasti, 2019; de la Torre, 2013).

Despite the existence of substantive literature on the rightwing populists and the profiles of their support bases (Pauwels, 2014; Rooduijn, 2018), few studies have focused on the comparison of these figures and technocratic leaders. This article aims to fill that gap. In this text, I focus on two countries, France and the Czech Republic, as examples of nations where technocratic leaders (Emmanuel Macron and Andrej Babiš) were electorally successful in the last decade. I analyze similari- 
ties and differences between technocratic leaders and rightwing populists in their respective countries (namely, Marine Le Pen and Tomio Okamura). In this study, I find that while all such leaders use anti-establishment and monist appeals, the salience of populist elements in their platforms varies quite dramatically. In contrast to rightwing populists, technocratic leaders lack a distinctive ideological profile and offer a broader, more inclusive vision of the community of people whose interests they claim to represent, as opposed to a more exclusive nativist vision of 'the people' that is offered by rightwing populists.

In addition, I also find that the parties led by these politicians tend to attract vastly different electorates. Using the European Social Survey (ESS) data, I compare voters of these parties in their respective countries. The results show that while Le Pen's FN and Okamura's Freedom and Direct Democracy attract similar social groups from lower socioeconomic strata, as well as voters with Eurosceptic, anti-establishment and anti-immigration attitudes, supporters of the parties led by Macron and Babiš tend to cut across class lines, differ in their positions on Euroscepticism and immigration, and have higher (rather than lower) levels of institutional trust. Therefore, being distinctly different from supporters of rightwing populist parties, the electorates of La Republique en Marche! (LaREM) and ANO 2011 (Action of Dissatisfied Citizens) have few commonalities between each other, if any.

Relatively few examples of such political leadership, lack of a distinct ideological profile, and variation of their support groups suggests that one should use caution when conceptualizing technocratic populists as a distinct theoretical type.

\section{Commonalities between Rightwing and Technocratic Populists}

The most widely accepted definition of populism focuses on its tendency to assign a binary moral dimension to political conflicts by drawing a Manichean distinction between the 'good people' and the 'bad elites' (Hawkins, 2009, 2010; Mudde, 2004, 2007; Mudde \& Kaltwasser, 2017). Populists, therefore, are monists in the sense that they tend to conceive of society as a singular unitary body (Canovan, 1981; Taggart, 2004). Populists are 'people-centrist' in that they argue that the will of the people should be the point of departure for all political decision-making and claim to represent the 'people,' a vaguely-defined homogeneous entity which could refer to a nation, ethnic group, culture, religion, civilization, etc. (Müller, 2016; Rooduijn, 2018; Taggart, 2000). Populists are also anti-establishment-that is, they accuse the 'elite' of being incompetent or corrupt (Barr, 2009; Canovan, 2002). Paradoxically, rising to power and becoming members of the elite themselves does not dissuade populists from using this rhetoric. When in power, populists continue to use anti-elite appeals to demobilize and delegitimize their opponents (Buštíková \& Guasti, 2019).

The thin nature of the populist ideology allows it to combine with additional ideological elements (Mudde \& Kaltwasser, 2017; Zulianello, 2020). As a result, scholars often find 'populist' parties on both sides of the political spectrum.

In recent years, scholarship has devoted particular attention to a broad category of rightwing populists. In the past, radical right populists used to be selected as a separate conceptual category, yet in recent years, many of these figures have moderated their previously radical stances on ethnic minorities and immigration (Héjj, 2017; Mondon, 2017). As a result, their platforms became less extremist, and now they are often grouped together in one conceptual category with national-conservative populists and radicalized mainstream politicians (Zulianello, 2020). The key commonality across all these actors is that they tend to combine their populist anti-establishment overtones with nativism, an ideology which holds that states should be inhabited exclusively by members of the native group and that non-native elements (persons and ideas) are fundamentally threatening to the homogenous nation-state (Mudde, 2007, p. 19; Mudde, 2010).

In their populist appeals, rightwing populists often rhetorically intertwine the defense of 'the people' with the defense of an ethnicity, culture, or nation (Jenne, 2018; Vachudova, 2020). For example, in the Czech Republic, Tomio Okamura's rightwing populist party Dawn of Direct Democracy has politicized the divide between the 'citizens' and the elites. The party received almost 7\% in the 2013 parliamentary election vote; however, in 2015, the party split and several of its members, including Okamura, founded a new political party dubbed Freedom and Direct Democracy (SPD). In the 2017 parliamentary elections, the SPD entered the Chamber of Deputies with the fourth result. In his public speeches, Okamura portrays himself as the ultimate guardian of the 'will of the people' while attacking the alleged enemies of the 'people' - that is, mainstream Czech politicians, mainstream media, and the European Union (Chovanec, 2020). His party's platform describes political elites in the Czech Republic as "godfather party mafias" and offers removal of established politicians as the solution for the country's problems (Úsvit prímé demokracie, 2013). These populist appeals are mixed with explicitly nativist overtones through an emphasis on the threat of immigrants allegedly taking away Czech citizens' jobs, as shown by the slogan "support to families, not to unadaptables. Work to our [people], not to immigrants" (Kim, 2020).

Similarly, another rightwing populist, a leader of the FN, Marine Le Pen, presents herself as "the voice of the people, the spirit of France" and the representative of the French "honest and hard-working people" who are governed by "corrupt elites" (Stockemer \& Barisione, 2017). The populist overtones of these appeals have a distinctly anti-establishment and nativist 
element. The FN advances an exclusionist, ethno-cultural conception of the people by portraying immigration as a "threat to national identity" and a burden for the French welfare system and finances. This threat, according to the FN, calls for the enforcement of "national priority" (Ivaldi, Lanzone, \& Woods, 2017). In the 2012 and 2017 parliamentary elections, the FN won $13.6 \%$ and $13.2 \%$ of votes respectively, and in the 2017 French presidential election, Marine Le Pen made it to the presidential runoff.

The second group, technocratic leaders, also portray the society as being in a state of a Manichean struggle between the 'bad elites' and the 'good people' whose interests they claim to represent. However, instead of nativist ideology, these leaders employ a more inclusive vision of 'the people' and combine populist appeals to ordinary people with promises to resolve societal problems through their own technocratic competence (Havlík, 2019). Andrej Babiš in the Czech Republic and Emmanuel Macron in France are often used as examples of such political leadership (Buštíková \& Guasti, 2019; Havlík, 2019; Maynard \& Lahdelma, 2018).

These leaders tend to marry technocracy with populism by creating an anti-establishment and anti-elitism rhetoric which combines attacks on the corruption of the established parties with technocratic promises that target the inability of established parties to deliver in terms of governance (Bickerton \& Accetti, 2018; Buštíková \& Guasti, 2019; Guasti, 2020). Both Andrej Babiš and Emmanuel Macron emphasize their technocratic credentials as a tool to solve the challenges faced by their respective societies. Babiš, for example, has repeatedly stressed that he does not trust traditional politics, and has advocated for a different, managerial approach to politics where ministers are experts rather than career politicians. Babiš portrays himself as an outsider of the system, that is, not a politician, but an amicable, philanthropic manager who knows how to care for those in his charge (Engler, Pytlas, \& Deegan-Krause, 2019; Kopeček, 2016). Babiš' party ANO 2011 has fiercely criticized established political parties for the alleged corrupt behavior of their representatives (Havlík, 2019). ANO offered to "make everything better for the ordinary people" through an "expert and businesslike" governance style which runs "the state as a firm" (Buštíková \& Guasti, 2019; Guasti \& Buštíková, 2020). High salience of anticorruption and anti-elitism distinguished ANO from other Czech parties (Havlík, 2019) and helped it become the most successful Czech political party since the fall of communism. Notably, ANO received about $19 \%$ and $30 \%$ of the vote in the 2013 and the 2017 elections.

Another example of technocratic leadership is France's Emmanuel Macron, who achieved a landslide victory in the 2017 presidential elections by receiving $66.1 \%$ of the vote. His party LaREM subsequently secured a majority in the French legislative elections. Macron's program can be described as populist, especially given his continuous portrayal of French society as being divided into two camps - the backward-looking conservatives and the progressive reformers. He makes an explicit connection between national sovereignty and reclaimed agency for ordinary people (Fougère \& Barthold, 2020). Macron's populist rhetoric disqualified the two traditional (left and right) ruling parties as part of the failed, old-guard elites, while portraying himself as an outsider of the system and emphasizing the "modest backgrounds" his parents came from (Macron, 2017 , p. 17). Macron has also described himself as a political leader who is uniquely capable, through the expert knowledge he gained working as a Minister of Economy under former president François Hollande, to address problems facing the French people. While in power, Macron continued using populist appeals, claiming to defend his expert decision-making on behalf of the peoples' interests against those of the illegitimate, imprudent elites on the other side of the society (Perottino \& Guasti, 2020). These anti-establishment tones were also reflected in Macron's En Marche! movement, which subsequently transformed into the political party La Republique en Marche! Upon its founding, consistent with Macron's anti-establishment discourse, the party did not accept members of other political parties or established politicians. Instead, LaREM was comprised of local online-constituted committees with no formal hierarchy (Fougère \& Barthold, 2020). Subsequently, the salience of anti-elite themes remained high for LaREM in comparison to most other French parties (except FN and Unbowed France; Perottino \& Guasti, 2020).

Direct ideological appeals to 'the people' over the heads of 'the discredited elites' is the key reason why political leaders as different as Tomio Okamura, Marine Le Pen, Andrej Babiš and Emmanuel Macron are 'lumped' together as populists. However, rather than being an end in itself, these appeals often reflect the current crisis within political systems from which these politicians tend to emerge. Anti-establishment sentiment flourishes in an atmosphere of declining political trust, critical evaluation of political parties, and negative attitudes toward politicians and politics in general (Kriesi, 2018). Studies have found a direct link between policy convergence of the political mainstream and a subsequent emergence of populist parties that offer alternative policy options (Arzheimer \& Carter, 2006; Kitschelt \& McGann, 1997; Meguid, 2005). Failure of mainstream parties to truly represent the interests of their voters erodes their own support, decreases satisfaction with democracy, and contributes to the electoral success of populists (Caiani \& Graziano, 2019; Kriesi \& Pappas, 2015). The populist platforms of the rising challengers that emphasize their appeal to 'ordinary people' over the allegedly corrupt or malevolent elites is often a natural response to the existing dissatisfaction of their voters with the political establishment.

All of these parties and leaders, therefore, tend to come to power in an atmosphere of declining trust in established parties. Since populists are a response to 
popular dissatisfaction with political mainstream, it is not surprising that electoral successes of technocrats and rightwing populists go hand in hand-both reflect voters' dissatisfaction with traditional politics. For example, the rise of Macron in France occurred amidst a growing distrust of political leaders and institutions, which fueled the rise of populist parties and drove voter abstention to unprecedented levels (Chamorel, 2019). The emergence of Macron coincided with a surge in popularity of Marine Le Pen, with whom he competed in the runoff of the 2017 presidential elections. Macron's 2017 election victory was, to a large extent, a function of his outsider status, the collapse of the traditional political establishment, and the rejection of Le Pen's rightwing populism. Similarly, in the Czech Republic, ANO's success in the 2013 and 2017 parliamentary elections coincided with the rise of the Dawn/SPD.

However, while studies have paid particular attention to rightwing populist parties in the context of their responses to widespread disillusionment with the country's ruling elite and claims to restore responsiveness in the political system, few have analyzed a second type-the technocratic populist response and characteristics of their support bases (Caramani, 2017; Dargent, 2015).

\section{Differences between Rightwing and Technocratic Populists}

Similarities in these leaders' discourse should not conceal critical differences between rightwing populists and technocrats.

First, technocratic leaders are often described as non-ideological, "ideologically unfocused" (Havlík, 2019), or ideologically "thin" (Buštíková \& Guasti, 2019). This vagueness is strategic in so far as it enables these leaders to overcome the left-right divide and combine a broad variety of policies across both sides of the political spectrum (Guasti, 2020). Unconstrained by the need of ideological consistency, technocrats have the flexibility to choose from a wide array of policies, including both redistributive and/or neoliberal policies (Guasti, 2020). In recent years, for example, ANO, a party that originally embraced neoliberal policies consistent with Babiš's self-portrayal as a businessman, has moved to the left on economy and has used targeted welfare policies to buy off segments of the electorate. Ideological vagueness like this makes it harder to classify these political actors into one homogeneous party family.

ANO, for instance, comes up ideologically short in comparison to many ideologically-driven rightwing populist parties (Hanley \& Vachudova, 2018). Babiš is primarily a pragmatic businessman, that is, a manager rather than a politician, whose idea of effective governing is to run the country like a company (Pehe, 2018). This made some scholars reluctant to classify ANO as a populist party (Engler et al., 2019). Similarly, Macron's 2017 electoral campaign adopted a deliberate ideological vagueness by describing himself as "both rightwing and left-wing" (Fougère \& Barthold, 2020). To preserve this ideological ambiguity, Macron even delayed publishing his electoral program until less than two months before the presidential election. This delay made some observers argue that "it is inconceivable that candidates for the highest office in any other major democracy would express themselves [so vaguely]" (Fougère \& Barthold, 2020; Hazareesingh, 2017), while making some question to what extent Macron could be described as a populist (Jones, 2017).

Second, unlike rightwing populists, technocrats do not define 'the people' in strictly nativist terms. In contrast to rightwing populists, they adopt more inclusive rhetoric by appealing to a broadly defined community of people.

Andrej Babiš' discourse, for example, does not describe the Czech Republic in nativist terms. Instead, it presents the country as a land of people who are exceptional for their diligence, extraordinary manual skills, brightness, and wit (Havlík, 2019). ANO defines itself as a party for everyone that cross-cuts existing cleavages (Buštíková \& Guasti, 2019). Similarly, Macron's 2017 electoral rhetoric cut across partisan, ethnic, and religious lines by offering a broader notion of community and attempting to "bring together people from the left, center and right who want to work together" (Fougère \& Barthold, 2020). Macron criticized Marine Le Pen, a leader of the rightwing populist FN party, for her adoption of divisive "hate-filled speeches" towards minorities, while portraying himself as being more inclusive of all French people (Cuny, 2017).

\section{Variation across Electorates}

As a result of these important differences, rightwing populists and technocrats should attract supporters who, while all dissatisfied with mainstream politics, represent different social groups, socioeconomic statuses, and attitudinal characteristics.

Scholarship on populism in Europe has argued that supporters of populist parties have a number of commonalities.

First, studies in Western Europe have found that rightwing populist parties tend to attract supporters with lower socioeconomic status, especially workingclass electorates, a phenomenon that became known in the literature as "proletarization" of the populist right vote (Arzheimer, 2013; Lubbers, Gijsberts, \& Scheepers, 2002; Oesch, 2008; Spies, 2013). In Central and Eastern European contexts, however, the impact of individual socioeconomic status on the support for these parties is less straightforward. Some studies found that while working-class constituencies in Hungary supported populist right parties (Győri, 2015; Knutsen, 2013), in countries like the Czech Republic and Slovakia these groups were more likely to associate with left-oriented parties (Hloušek \& Kopeček, 2008; Linek, 2015). This relationship 
between socioeconomic status and support for rightwing populists might be conditioned by the economic positions of competing parties (Snegovaya, 2020).

In contrast to rightwing populists, the more inclusive appeals of the technocrats should cut across class lines, while their emphasis on the importance of expertise and qualifications should appeal to more educated voters. In line with this expectation, earlier studies have demonstrated that unlike support for other Czech parties, support for ANO is not predicted by ideology, policy attitudes, or a specific social class (Havlík \& Voda, 2018; Maškarinec, 2017). Macron's electoral base was found to be disproportionately urban, financially well-off, and well-educated (Chamorel, 2019).

I therefore expect rightwing parties to attract working-class electorates, while technocratic parties attract voters across class lines.

Second, studies of populism have identified that populist voters tend to have lower levels of trust in established parties and politicians. This stems from the nature of the populist parties that politicize anti-elite sentiment and attack political establishments by presenting themselves as defenders of 'ordinary people' (Mair, 2002; Mudde, 2007). Studies have found that such ideological appeals attract voters who are dissatisfied with political establishments and have higher levels of political mistrust (Norris \& Inglehart, 2019; Oesch, 2008; Santana, Zagórski, \& Rama, 2020).

I therefore expect both types of populist parties to attract voters with lower levels of political trust.

Third, populist voters also tend to be more Eurosceptic, due to the anti-establishment nature of such parties. Euroscepticism may be understood as an 'anti-political establishment' position (Schedler, 1996) that affords populist parties an issue in which they might cast themselves in opposition to the political class as a whole (Harmsen, 2010). Populist parties often channel the disaffection of their voters with mainstream politics by questioning European integration and depicting the European Union as a threat to the identity and nationhood of their respective societies. As a result, studies have found that supporters of populist parties tend to be Eurosceptic (Ramiro, 2016; Visser, Lubbers, Kraaykamp, \& Jaspers, 2014; Werts, Scheepers, \& Lubbers, 2013).

I therefore expect both rightwing populists and technocrats to attract voters with higher levels of Euroscepticism.

Ultimately, in recent years, following the wave of refugees that entered Europe in 2015, the anti-EU sentiment has become closely linked to an opposition to immigration and open borders. The subsequent surge in support for populist right parties has been linked to the growth in levels of immigration to Europe (Grzymala-Busse, 2019; Norris \& Inglehart, 2019, p. 179). These anti-immigration views should be primarily associated with support of rightwing populists whose nativist stances mix well with rejection of immigration (Allen, 2017; Arzheimer \& Berning, 2019; Shehaj, Shin,
\& Inglehart, 2019). While nativism is conceptually distinct from attitudes towards immigration, it is inherently linked to the idea that immigrants represent a "cultural threat" (Knoll, 2013), and has previously been shown to have a significant effect on immigration attitudes and immigration-related policy preferences (Citrin \& Sides, 2008).

I therefore expect anti-immigration stances to be more pronounced among supporters of rightwing populists.

While many papers have focused on the electorates of rightwing populists, few have attempted to analyze them in comparison to supporters of technocrats. In the following sections, this article fills in this gap by focusing on socioeconomic and attitudinal characteristics across the electorates of parties led by Macron's LaREM in France and Babiš's ANO 2011 in the Czech Republic, and contrasts them to supporters of rightwing populist parties FN and Dawn/SPD in their respective countries. First, I focus on various sociodemographic indicators, like education, income, and social class, that might predict support for these parties. Second, I focus on the attitudinal preferences of these electorates, specifically analyzing their levels of trust in political institutions (a proxy for anti-establishment sentiment), Euroscepticism, and anti-immigration attitudes, in comparison to supporters of mainstream parties in respective countries.

\section{Data and Analytical Procedure}

For my analysis, I devised a study modeled after previous research (Allen, 2017; Rooduijn, 2018; Santana et al., 2020). The analysis is set at the individual level and is based on the data from the ESS, which is collected biennially in 2014, 2016, and 2018, when data on parties in their respective countries is available.

The dependent variable is based on the ESS question: "Which party did you vote for in the last election?" I recoded this variable so that a respondent scores a " 1 " if they voted for one of the analyzed parties, and a " 0 " if they voted for one of the mainstream parties in the parliament at the time of the survey. If a respondent voted for another party, this variable was set to missing.

All regressions include a number of sociodemographic variables: sex, age, quadratic age term, education (primary-base category, secondary and tertiary), household's net income, and unemployment status. To control for respondents' occupational status, I used the commonly-employed Erikson-GoldthorpePortocarero classification schema, which transforms the ISCO-88 codes into the following categories: 1) "highergrade professionals"; 2) "lower-grade professionals"; 3) "routine non-manual employees in administration and commerce, sales personnel, other rank-and fileemployees"; 4) "small proprietors including farmers and smallholders"; 5) "skilled manual workers and manual supervisors"; 6) "semi- and unskilled manual workers" (Erikson, Goldthorpe, \& Portocarero, 1979; Hendrickx, 
2002). The "higher-grade professionals" were chosen as the base category.

The level of political mistrust, which is commonly used in the literature as a proxy for anti-establishment sentiment (Santana et al., 2020), was measured based on three correlated (0-10 scale) standardized variables that asked about respondents' levels of trust in political parties, politicians, and a country's parliament (Cronbach's $\alpha=0.74)$. The lower value of the coefficient of this variable corresponds to lower levels of institutional trust.

Euroscepticism is measured using the ESS 11-points question about whether European unification has already gone too far (0) or should go further (10). The negative coefficient of this variable indicates higher levels of Euroscepticism.

To control for immigration attitudes, I performed a factor analysis of three highly-correlated (0-10 scale) standardized variables that asked about respondents' attitudes toward immigrants (Cronbach's $\alpha=0.87$ ). The questions asked to assess whether immigrants are bad (0) or good (10) for the economy, undermine (0) or enrich (10) culture, or generally make the respondent's country "worse" (0) or "better" (10).

Because of the binary nature of the dependent variable, I ran probit models controlling for a linear year trend to account for time-level variation. The observations were weighted using the ESS design weights to correct for the fact that respondents in different countries have different probabilities of being sampled. Observations with missing values were deleted.

While the data on ANO, Dawn/SPD, and FN is available for 2014, 2016, and 2018, Macron's LaREM party was absent before 2017.

Instead of a pooled analysis, I analyzed the electorates of all of the selected parties separately. The reason I chose to run separate regressions for each selected party is that the effects discovered from a pooled analysis may confound important variation on the country-level and overestimate the effects of the variables of interest.

\section{Findings}

For the sake of my analysis, the size of the effects is less important than their sign and significance. Hence the below Tables 1 and 2 provide an overview of the direction of the regression coefficients and show whether they are positive or negative. Marginal effects are provided in the Supplementary File, Appendix II.

Table 1 focuses on the electorates of rightwing populist parties Dawn/SPD in the Czech Republic and the FN in France in comparison to supporters of mainstream parties in parliament at the time of the analysis. The Dawn of Direct Democracy party fell apart in May 2015, when a number of MPs split from it and founded a new party (SPD). Both parties attract similar type of supporters (Kaniok \& Hloušek, 2018). To preserve a higher num- ber of observations, I analyzed supporters of the Czech parties Dawn and SPD together. Columns (1) and (3) include basic sociodemographic controls, while columns (2) and (4) add in the analysis attitudinal characteristics of their voters.

Overall, the findings in Table 1 go in line with the expectations and previous literature on this topic. First, in terms of their socioeconomic status (columns (1) and (3) in Table 1), supporters of rightwing populists tend to be working class (in case of FN) and low controllers' status (in case of Dawn/SPD). This is consistent with the literature which found that while in the Western European context there is a strong link between working-class status and rightwing populist vote, in Central and Eastern Europe this association is less straightforward. There is also a consistent negative association between age and support for right populist parties, suggesting that younger voters are more likely to vote for such parties.

Second, based on the coefficients in Table 1 (columns (2) and (4)), supporters of rightwing populist parties in both countries have significantly lower levels of trust in political institutions, and higher levels of Euroscepticism and anti-immigration sentiment. Marginal effects (Table 4 in the Supplementary File, Appendix II) suggest that the size of the effect is larger for the immigration variable, which is consistent with the emphasis these parties make on nativism. This goes in line with earlier studies that have identified these characteristics as distinguishing the electorates of rightwing populists from voters of other parties. In other words, rightwing populists constitute a coherent party family which unites parties that are ideologically close and attracts similar types of supporters.

Next, I repeat this analysis by focusing on parties led by technocratic leaders in respective countries. Table 2 focuses on voters of ANO and LaREM in comparison to supporters of other mainstream parties in parliament at the time of the survey. Columns (1) and (3) include respondents' basic sociodemographic controls, while columns (2) and (4) add their attitudinal characteristics.

First, in terms of their socioeconomic status (columns (1) and (3) in Table 2), supporters of ANO and LaREM do not seem to have many characteristics in common and do not differ much from the electorates of mainstream parties. Here, the effect of education is not consistent (the effects of the education variable disappear after the inclusion of attitudinal variables). Overall, the results are somewhat in line with the original expectationstechnocratic populists cut across class lines and appeal to voters belonging to various socioeconomic groups.

Second, in terms of their attitudinal characteristics (columns (2) and (4) in Table 2), the results also do not confirm the expectations. The only variable whose coefficient is consistent across ANO and LaREM is institutional trust, but the sign of the coefficient goes in the direction opposite to the expectations-the supporters of these parties have higher levels of trust in political institutions as compared to voters of mainstream parties. One pos- 
Table 1. Probit regression model explaining voting for rightwing populist parties (mainstream parties in parliament as base category).

\begin{tabular}{|c|c|c|c|c|}
\hline & $\begin{array}{c}(1) \\
\text { Dawn/SPD }\end{array}$ & $\begin{array}{c}(2) \\
\text { Dawn/SPD }\end{array}$ & $\begin{array}{l}(3) \\
\text { FN }\end{array}$ & $\begin{array}{l}(4) \\
\text { FN }\end{array}$ \\
\hline Male & $\begin{array}{c}0.125 \\
(0.096)\end{array}$ & $\begin{array}{l}0.223^{* * *} \\
(0.107)\end{array}$ & $\begin{array}{l}-0.285^{* * *} \\
(0.146)\end{array}$ & $\begin{array}{c}-0.187 \\
(0.165)\end{array}$ \\
\hline Age & $\begin{array}{l}-0.009 * * * \\
(0.003)\end{array}$ & $\begin{array}{l}-0.014 * * * \\
(0.003)\end{array}$ & $\begin{array}{l}-0.024 * * * \\
(0.005)\end{array}$ & $\begin{array}{l}-0.033^{* * *} \\
(0.005)\end{array}$ \\
\hline Unemployed & $\begin{array}{c}0.200 \\
(0.260)\end{array}$ & $\begin{array}{c}0.178 \\
(0.286)\end{array}$ & $\begin{array}{c}-0.707 \\
(0.605)\end{array}$ & $\begin{array}{c}-0.550 \\
(0.615)\end{array}$ \\
\hline Income & $\begin{array}{c}-0.052 \\
(0.042)\end{array}$ & $\begin{array}{l}-0.079 * * * \\
(0.044)\end{array}$ & $\begin{array}{c}-0.056 \\
(0.080)\end{array}$ & $\begin{array}{c}-0.080 \\
(0.090)\end{array}$ \\
\hline \multicolumn{5}{|l|}{ Education: } \\
\hline Secondary & $\begin{array}{l}0.431 * * * \\
(0.223)\end{array}$ & $\begin{array}{l}0.488^{* * *} \\
(0.239)\end{array}$ & $\begin{array}{c}-0.153 \\
(0.185)\end{array}$ & $\begin{array}{c}0.040 \\
(0.207)\end{array}$ \\
\hline Tertiary & $\begin{array}{c}0.211 \\
(0.244)\end{array}$ & $\begin{array}{c}0.322 \\
(0.260)\end{array}$ & $\begin{array}{c}-0.942 * * * \\
(0.258)\end{array}$ & $\begin{array}{c}-0.581^{* * *} \\
(0.287)\end{array}$ \\
\hline \multicolumn{5}{|l|}{ Socio-economic status: } \\
\hline Low controllers & $\begin{array}{l}0.311^{* * *} \\
(0.155)\end{array}$ & $\begin{array}{l}0.429 * * * \\
(0.178)\end{array}$ & $\begin{array}{c}0.414 \\
(0.311)\end{array}$ & $\begin{array}{c}0.427 \\
(0.398)\end{array}$ \\
\hline Routine nonmanual & $\begin{array}{c}0.048 \\
(0.163)\end{array}$ & $\begin{array}{c}0.170 \\
(0.186)\end{array}$ & $\begin{array}{c}0.288 \\
(0.335)\end{array}$ & $\begin{array}{c}0.388 \\
(0.407)\end{array}$ \\
\hline Self-employed & $\begin{array}{c}0.150 \\
(0.186)\end{array}$ & $\begin{array}{c}0.249 \\
(0.207)\end{array}$ & $\begin{array}{l}0.749 * * * \\
(0.349)\end{array}$ & $\begin{array}{c}0.376 \\
(0.477)\end{array}$ \\
\hline Skilled manual & $\begin{array}{c}0.012 \\
(0.177)\end{array}$ & $\begin{array}{c}-0.005 \\
(0.207)\end{array}$ & $\begin{array}{l}0.836^{* * *} \\
(0.355)\end{array}$ & $\begin{array}{l}0.766^{* * * *} \\
(0.441)\end{array}$ \\
\hline Semi-unskilled manual & $\begin{array}{c}0.115 \\
(0.164)\end{array}$ & $\begin{array}{c}0.130 \\
(0.191)\end{array}$ & $\begin{array}{l}0.702^{* * *} \\
(0.321)\end{array}$ & $\begin{array}{c}0.475 \\
(0.391)\end{array}$ \\
\hline Trust in institutions & & $\begin{array}{l}-0.171 * * * \\
(0.056)\end{array}$ & & $\begin{array}{c}-0.233^{* * *} \\
(0.113)\end{array}$ \\
\hline European unification go further & & $\begin{array}{l}-0.128^{* * *} \\
(0.055)\end{array}$ & & $\begin{array}{c}-0.262^{* * *} \\
(0.085)\end{array}$ \\
\hline Immigration & & $\begin{array}{l}-0.260 * * * \\
(0.059)\end{array}$ & & $\begin{array}{l}-0.655^{* * *} \\
(0.094)\end{array}$ \\
\hline ESS round & $\begin{array}{l}0.097 * * * \\
(0.052)\end{array}$ & $\begin{array}{l}0.104^{* * *} \\
(0.058)\end{array}$ & & \\
\hline Constant & $\begin{array}{l}-2.426^{* * *} \\
(0.525)\end{array}$ & $\begin{array}{l}-2.417 * * * \\
(0.596)\end{array}$ & $\begin{array}{c}0.375 \\
(0.464)\end{array}$ & $\begin{array}{c}0.875 \\
(0.553)\end{array}$ \\
\hline Observations & 3,325 & 3,048 & 777 & 737 \\
\hline r2_p & 0.0291 & 0.102 & 0.158 & 0.377 \\
\hline
\end{tabular}

Note: ${ }^{* *} \mathrm{p}<0.01,{ }^{* *} \mathrm{p}<0.05,{ }^{*} \mathrm{p}<0.1$.

sible explanation is that both ANO and LaREM were in power at the time of the study, and hence higher levels of institutional trust may reflect their voters' satisfaction with the political institutions that allowed these parties to win (Petrova \& Snegovaya, 2020). However, this result contradicts the original expectation, as well as the essence of populist ideology, which tends to mobilize voters through anti-elitist messages (Hameleers et al., 2018).

In reference to Euroscepticism and anti-immigration attitudes, the results are also not consistent across both parties. While ANO, as expected, tends to attract more
Eurosceptic voters than other parties, supporters of LaREM do not differ from mainstream parties on their levels of Euroscepticism. Additionally, Macron's voters tend to be more oriented in favor of immigration, while Babiš' voters do not differ on this issue from voters of other parties.

Overall, these findings demonstrate that while supporters of the rightwing populist parties tend to have similar attitudinal preferences, voters of parties led by technocratic leaders represent quite different social groups, especially in relation to their socioeconomic status and attitudinal characteristics. Supporters of these 
Table 2. Probit regression model explaining voting for technocratic parties (mainstream parties in parliament as base category).

\begin{tabular}{|c|c|c|c|c|}
\hline & $\begin{array}{c}(1) \\
\text { ANO }\end{array}$ & $\begin{array}{c}(2) \\
\text { ANO }\end{array}$ & $\begin{array}{c}(3) \\
\text { LaREM }\end{array}$ & $\begin{array}{c}(4) \\
\text { LaREM }\end{array}$ \\
\hline Male & $\begin{array}{c}-0.051 \\
(0.056)\end{array}$ & $\begin{array}{c}-0.052 \\
(0.058)\end{array}$ & $\begin{array}{c}0.164 \\
(0.115)\end{array}$ & $\begin{array}{c}0.158 \\
(0.122)\end{array}$ \\
\hline Age & $\begin{array}{l}-0.005^{* * *} \\
(0.002)\end{array}$ & $\begin{array}{c}-0.005 * * * \\
(0.002)\end{array}$ & $\begin{array}{c}0.005 \\
(0.004)\end{array}$ & $\begin{array}{c}0.006 \\
(0.004)\end{array}$ \\
\hline Unemployed & $\begin{array}{l}-0.424^{* * *} \\
(0.208)\end{array}$ & $\begin{array}{c}-0.417^{* * *} \\
(0.219)\end{array}$ & $\begin{array}{c}-0.316 \\
(0.389)\end{array}$ & $\begin{array}{c}-0.377 \\
(0.391)\end{array}$ \\
\hline Income & $\begin{array}{l}0.045^{* * *} \\
(0.026)\end{array}$ & $\begin{array}{c}0.045 \\
(0.028)\end{array}$ & $\begin{array}{c}0.052 \\
(0.069)\end{array}$ & $\begin{array}{c}0.025 \\
(0.074)\end{array}$ \\
\hline \multicolumn{5}{|l|}{ Education: } \\
\hline Secondary & $\begin{array}{l}0.229 * * * \\
(0.113)\end{array}$ & $\begin{array}{c}0.193 \\
(0.120)\end{array}$ & $\begin{array}{c}0.065 \\
(0.173)\end{array}$ & $\begin{array}{c}0.038 \\
(0.189)\end{array}$ \\
\hline Tertiary & $\begin{array}{c}0.172 \\
(0.124)\end{array}$ & $\begin{array}{c}0.171 \\
(0.130)\end{array}$ & $\begin{array}{l}0.399 * * * \\
(0.194)\end{array}$ & $\begin{array}{c}0.198 \\
(0.210)\end{array}$ \\
\hline \multicolumn{5}{|l|}{ Socio-economic status: } \\
\hline Low controllers & $\begin{array}{c}0.021 \\
(0.088)\end{array}$ & $\begin{array}{c}-0.019 \\
(0.091)\end{array}$ & $\begin{array}{c}-0.207 \\
(0.163)\end{array}$ & $\begin{array}{c}-0.181 \\
(0.167)\end{array}$ \\
\hline Routine nonmanual & $\begin{array}{c}0.036 \\
(0.092)\end{array}$ & $\begin{array}{c}0.035 \\
(0.096)\end{array}$ & $\begin{array}{c}-0.340 * * * \\
(0.199)\end{array}$ & $\begin{array}{l}-0.395^{* * *} \\
(0.204)\end{array}$ \\
\hline Self-employed & $\begin{array}{c}-0.011 \\
(0.114)\end{array}$ & $\begin{array}{c}-0.082 \\
(0.121)\end{array}$ & $\begin{array}{c}-0.378 \\
(0.254)\end{array}$ & $\begin{array}{c}-0.413 \\
(0.269)\end{array}$ \\
\hline Skilled manual & $\begin{array}{c}0.077 \\
(0.098)\end{array}$ & $\begin{array}{c}0.063 \\
(0.103)\end{array}$ & $\begin{array}{c}-0.246 \\
(0.296)\end{array}$ & $\begin{array}{c}-0.190 \\
(0.311)\end{array}$ \\
\hline Semi-unskilled manual & $\begin{array}{c}-0.057 \\
(0.096)\end{array}$ & $\begin{array}{c}-0.045 \\
(0.100)\end{array}$ & $\begin{array}{c}-0.582^{* * *} \\
(0.229)\end{array}$ & $\begin{array}{c}-0.609 * * * \\
(0.239)\end{array}$ \\
\hline Trust in institutions & & $\begin{array}{l}\text { 0.088*** } \\
(0.031)\end{array}$ & & $\begin{array}{l}0.238 * * * \\
(0.079)\end{array}$ \\
\hline European unification should go further & & $\begin{array}{c}-0.051 * * * \\
(0.031)\end{array}$ & & $\begin{array}{c}0.101 \\
(0.065)\end{array}$ \\
\hline Immigration & & $\begin{array}{c}-0.023 \\
(0.035)\end{array}$ & & $\begin{array}{l}0.192 * * * \\
(0.072)\end{array}$ \\
\hline ESS round & $\begin{array}{l}0.065^{* * *} \\
(0.031)\end{array}$ & $\begin{array}{c}0.049 \\
(0.033)\end{array}$ & & \\
\hline Constant & $\begin{array}{l}-1.039 * * * \\
(0.313)\end{array}$ & $\begin{array}{c}-0.816^{* * *} \\
(0.336)\end{array}$ & $\begin{array}{c}-0.896 * * * \\
(0.389)\end{array}$ & $\begin{array}{c}-1.078^{* * *} \\
(0.422)\end{array}$ \\
\hline Observations & 3,179 & 2,917 & 680 & 644 \\
\hline r2_p & 0.0103 & 0.0118 & 0.0500 & 0.0988 \\
\hline
\end{tabular}

Note: $* * * p<0.01, * * p<0.05, * p<0.1$.

parties vary dramatically in terms of their stances on Euroscepticism, and, contrary to expectation, show higher levels of trust in political institutions than voters of other mainstream parties. This last finding should be interpreted as a warning against theorizing the technocratic populist parties as a distinct theoretical concept, as this contradicts the core of populism-its anti-elitist message.

\section{Discussion and Conclusion}

In this article, I have looked at two types of political actors who are commonly described as 'populist' in literature-namely, rightwing populists and technocratic leaders. I have analyzed similarities and differences in the platforms of these leaders and their respective parties. In addition, I have empirically compared the electorates of parties led by technocratic leadersEmmanuel Macron's Republic en Marche in France and Andrej Babiš's ANO 2011 in the Czech Republic against the electorates of rightwing populists in their respective countries, namely, the FN led by Marine Le Pen and Dawn/SPD led by Tomio Okamura.

While both types of political actors tend to emerge in response to a decline in trust in established parties 
and adopt platforms with anti-establishment and monist elements, they are also quite different. In contrast to rightwing populists, technocrats deliberately adopt an 'ideological vagueness' that allows them more flexibility in choosing policies which ensure voter support and use a more inclusive notion of 'the people.'

While dissatisfied with established parties, supporters of rightwing populist and technocratic parties represent different social groups, especially in relation to their socioeconomic status and attitudinal characteristics. The rightwing populist parties (Dawn/SPD and National Front) tend to attract voters with lower levels of political trust, higher levels of Euroscepticism, and stronger anti-immigration preferences. These findings are consistent with existing literature on rightwing populists that has identified commonalities across these parties' electorates (Allen, 2017; Rooduijn, 2018; Santana et al., 2020). A distinct ideological profile coupled with specific social groups receptive to their narratives allows us to identify rightwing populist parties as an analytically distinct party family.

By contrast, the empirical analysis of Macron's LaREM and Babiš' ANO parties shows that while cutting across class lines, their supporters have few commonalities in their attitudinal characteristics. These parties' electorates vary in terms of their stances on Euroscepticism and immigration attitudes. These results generally are backed by earlier studies which found that, for example, support for ANO is not predicted by specific ideology, policy attitudes, or a social class category (Havlík \& Voda, 2018; Maškarinec, 2017). The heterogeneity of their electorates is, at least, in part driven by the ideologic ambiguity of these parties and leaders, which allows them to attract diverse support.

In addition, contrary to previous expectations, I find that voters of LaREM and ANO have higher levels of trust in political institutions than voters of other mainstream parties. This finding is at odds with the heart of populist ideology, which tends to mobilize voters through anti-elitist appeals (Hameleers et al., 2018). Overall, these results cast doubts on arguments for classifying ANO and LaREM together into a distinct party family (Havlík \& Voda, 2018; Maškarinec, 2017).

While the rise of parties combining anti-establishment and monist appeals with an emphasis on technocratic governance can be attributed to a decline in trust in established party elites and rising corruption concerns, it is less clear to what extent these parties can be grouped into one analytical category. These parties adopt populist narratives in response to a perceived crisis of representation in their respective polities, but it is questionable whether they constitute one distinct ideological group of political actors. The relatively small number of such parties, the lack of a distinct ideological profile, and the variation of their support groups suggests that one should use caution when conceptualizing technocratic parties as a distinct theoretical type.
Scholars who have recognized this problem sometimes offer discourse, rather than ideology, as evidence for classification of 'technocratic populists' into a distinct party family. For example, Bickerton and Accetti (2018) argue, using the example of the Five Star Movement and Podemos, that these parties employ a unique type of rhetorical appeals which mix 'anti-system,' 'antiestablishment,' and 'populist' elements with 'technocratic' themes. Other studies, however, have shown that in recent years the number of various political actors (not just those usually labeled as populist) using anti-establishment rhetoric has increased dramatically in many European countries (Engler et al., 2019). Because of this, rhetorical appeals alone may not be sufficient to uniquely distinguish these parties as a separate family. In-depth quantitative analysis of their electoral platforms is needed to confirm that rhetorical appeals of technocratic parties and leaders are indeed distinctly different from those of other political actors.

There are several limitations of this study that should be acknowledged. First, the analysis in this article is limited to 2018, the last year for which ESS data is available. However, in recent years, Babiš and his party ANO have moved more to the left on economic policy to attract new segments of the electorate (including older people and pensioners) through targeted welfare policies. Future studies, therefore, may find that ANO support is more strongly associated with lower socioeconomic status, a fact which might render its voters' profiles closer to that of rightwing populists.

Second, the data availability has also limited the number of parties that could be included in the analysis. Ideally, future studies should expand the analysis to other technocratic leaders and parties, such as Silvio Berlusconi in Italy, Donald Trump in the United States, Bidzina Ivanishvili in Georgia, and Rafael Correa in Ecuador.

\section{Acknowledgments}

This publication has benefited greatly from comments by Lenka Buštíková, Petra Guasti, and Tsveta Petrova.

\section{Conflict of Interests}

The author declares no conflict of interests.

\section{Supplementary Material}

Supplementary material for this article is available online in the format provided by the author (unedited).

\section{References}

Allen, T. J. (2017). All in the party family? Comparing far right voters in Western and post-communist Europe. Party Politics, 23(3), 274-285.

Arzheimer, K. (2013). Working class parties 2.0? Competition between centre left and extreme right parties. 
In J. Rydren (Ed.), Class politics and the radical right (pp. 75-90). London and New York, NY: Routledge.

Arzheimer, K., \& Berning, C. (2019). How the Alternative for Germany (AfD) and their voters veered to the radical right, 2013-2017. Electoral Studies, 60. https:// doi.org/10.1016/j.electstud.2019.04.004

Arzheimer, K., \& Carter, E. (2006). Political opportunity structures and right-wing extremist party success. European Journal of Political Research, 45(3), 419-443.

Barr, R. R. (2009). Populists, outsiders and antiestablishment politics. Party Politics, 15(1), 29-48.

Bickerton, C. J., \& Accetti, C. I. (2018). 'Techno-populism' as a new party family: The case of the Five Star Movement and Podemos. Contemporary Italian Politics, 10(2), 132-150.

Buštíková, L., \& Guasti, P. (2019). The state as a firm: Understanding the autocratic roots of technocratic populism. East European Politics and Societies, 33(2), 302-330.

Caiani, M., \& Graziano, P. (2019). Understanding varieties of populism in times of crises. West European Politics, 42(6), 1141-1158.

Canovan, M. (1981). Populism. Boston, MA: Houghton Mifflin Harcourt.

Canovan, M. (2002). Taking politics to the people: Populism as the ideology of democracy. In Y. Mény \& Y. Surel (Eds.), Democracies and the populist challenge (pp. 25-44). London: Palgrave Macmillan.

Caramani, D. (2017). Will vs. reason: The populist and technocratic forms of political representation and their critique to party government. The American Political Science Review, 111(1), 54-67.

Chamorel, P. (2019). Macron versus the Yellow Vests. Journal of Democracy, 30(4), 48-62.

Chovanec, J. (2020). Performing populist style in context. In V. Lopičić \& B. M. Ilić (Eds.), Jezik, književnost, kontext [Language, literature, context] (pp. 31-44). Niš: University of Niš.

Citrin, J., \& Sides, J. (2008). Immigration and the imagined community in Europe and the United States. Political Studies, 56(1), 33-56.

Cuny, D. (2017, May 17). Qui est Mounir Mahjoubi le nouveau secrétaire d'Etat au numérique [Who is Mounir Mahjoubi, the new digital secretary of state]. L'Obs. Retrieved from http://tempsreel.nouvelobs. com/rue89/sur-le-radar/20160202.RUE2090/quiest-mounir-mahjoubi-le-nouveau-president-ducnnum.html

Dargent, E. (2015). Technocracy and democracy in Latin America: The experts running government. Cambridge: Cambridge University Press.

de la Torre, C. (2013). Latin America's authoritarian drift: Technocratic populism in Ecuador. Journal of Democracy, 24(3), 33-46.

Engler, S., Pytlas, B., \& Deegan-Krause, K. (2019). Assessing the diversity of anti-establishment and populist politics in Central and Eastern Europe. West Euro- pean Politics, 42(6), 1310-1336.

Erikson, R., Goldthorpe, J. H., \& Portocarero, L. (1979). Intergenerational class mobility in three Western European societies: England, France and Sweden. British Journal of Sociology, 30(4), 415-441.

Fougère, M., \& Barthold, C. (2020). Onwards to the new political frontier: Macron's electoral populism. Organization, 27(3), 419-430.

Gidron, N., \& Bonikowski, B. (2013). Varieties of populism: Literature review and research agenda (Weatherhead Working Paper Series, No. 13-0004). Harvard, MA: Weatherhead Center for International Affairs.

Grzymala-Busse, A. (2019). The failure of Europe's mainstream parties. Journal of Democracy, 30(4), 35-47.

Guasti, P. (2020). Populism in power and democracy: Democratic decay and resilience in the Czech Republic (2013-2020). Politics and Governance, 8(4), 473-484.

Guasti, P., \& Buštíková, L. (2020). In Europe's closet: The rights of sexual minorities in the Czech Republic and Slovakia. East European Politics, 36(2), 226-246.

Győri, G. (2015). Hungarian politics in 2014 (Policy Solution Research Papers). Bonn: Friedrich Ebert Foundation.

Hameleers, M., Bos, L., Fawzi, N., Reinemann, C., Andreadis, I., Corbu, N., . . . Axelsson, S. (2018). Start spreading the news: A comparative experiment on the effects of populist communication on political engagement in sixteen European countries. The International Journal of Press/Politics, 23(4), 517-538.

Hanley, S., \& Vachudova, M. A. (2018). Understanding the illiberal turn: Democratic backsliding in the Czech Republic. East European Politics, 34(3), 276-296.

Harmsen, R. (2010). Concluding comment: On understanding the relationship between populism and Euroscepticism. Perspectives on European Politics and Society, 11(3), 333-341.

Havlík, V. (2019). Technocratic populism and political illiberalism in central Europe. Problems of PostCommunism, 66(6), 369-384.

Havlík, V., \& Voda, P. (2018). Cleavages, protest or voting for hope? The rise of centrist populist parties in the Czech Republic. Swiss Political Science Review, 24(2), 161-186.

Hawkins, K. A. (2009). Is Chávez populist? Measuring populist discourse in comparative perspective. Comparative Political Studies, 42(8), 1040-1067.

Hawkins, K. A. (2010). Venezuela's Chavismo and populism in comparative perspective. Cambridge: Cambridge University Press.

Hazareesingh, S. (2017, May 9) Man of the people: The existential French election. The Times Literary Supplement, pp. 18-19.

Heinisch, R., \& Saxonberg, S. (2017). Entrepreneurial populism and the radical centre: Examples from Austria and the Czech Republic. In R. C. Heinisch, C. HoltzBacha, \& O. Mazzoleni (Eds.), Political populism (pp. 
209-226). Baden-Baden: Nomos Publishing.

Héjj, D. (2017). The rebranding of Jobbik. New Eastern Europe, 6(29), 83-90.

Hendrickx, J. (2002). ISKO: Stata module to recode 4-digit ISCO-88 occupational codes (Statistical Software Components S425802) [Computer software]. Boston, MA: Boston College Department of Economics.

Hloušek, V., \& Kopeček, L. (2008). Cleavages in the contemporary Czech and Slovak politics between persistence and change. East European Politics and Societies, 22(3), 518-552.

Ivaldi, G. (2018). Contesting the EU in times of crisis: The Front National and politics of Euroscepticism in France. Politics, 38(3), 278-294.

Ivaldi, G., Lanzone, M. E., \& Woods, D. (2017). Varieties of populism across a left-right spectrum: The case of the Front National, the Northern League, Podemos and Five Star Movement. Swiss Political Science Review, 23(4), 354-376.

Jenne, E. (2018). Is nationalism or ethno-populism on the rise today? Ethnopolitics, 17(5), 546-552.

Jones, E. (2017). The rise of populism and the fall of Europe. SAIS Review of International Affairs, 37(1), 47-57.

Kaniok, P., \& Hloušek, V. (2018). Brexit outside of UK politics: The case of Czech Eurosceptics. European politics and society, 19(5), 507-525.

Kim, S. (2020). Between illiberalism and hyperneoliberalism: Competing populist discourses in the Czech Republic. European Politics and Society, 21(5), 618-633.

Kitschelt, H., \& McGann, A. J. (1997). The radical right in Western Europe: A comparative analysis. Ann Arbor, MI: University of Michigan Press.

Knoll, B. R. (2013). Implicit nativist attitudes, social desirability, and immigration policy preferences. International Migration Review, 47(1), 132-165.

Knutsen, O. (2013). Social structure, social coalitions and party choice in Hungary. Communist and PostCommunist Studies, 46(1), 25-38.

Kopeček, L. (2016). "I'm paying, so I decide": Czech ANO as an extreme form of a business-firm party. East European Politics and Societies, 30(4), 725-749.

Kriesi, H. (2018). The determinants of the vote for the radical right and the radical left in Western Europe. Paper presented at the EUI Workshop on Populism, Fiesole, Italy.

Kriesi, H., \& Pappas, T. S. (Eds.). (2015). European populism in the shadow of the great recession. Colchester: ECPR Press.

Linek, L. (2015). Class, religion, and generations: Cleavage voting and the mediating role of party identification in the Czech Republic, 1990-2013. Paper presented at the ECPR Joint Sessions of Workshops, Warsaw, Poland.

Lubbers, M., Gijsberts, M., \& Scheepers, P. (2002). Extreme right-wing voting in Western Europe. European Journal of Political Research, 41(3), 345-378.
Macron, E. (2017). Révolution: Réconcilier la France [Revolution: Reconciling France]. Paris: XO Editions.

Mair, Peter (2002). Populist democracy vs party democracy. In Y. Mény \& Y. Surel (Eds.), Democracies and the populist challenge (81-98). Basingstoke: Palgrave.

Maškarinec, P. (2017). A spatial analysis of Czech parliamentary elections, 2006-2013. Europe-Asia Studies, 69(3), 426-457.

Maynard, S., \& Lahdelma, I. (2018). Macri and Macron: Why the Argentine and French presidents share more than their surnames. LSE European Politics and Policy Blog. Retrieved from https://blogs.Ise. ac.uk/europpblog/2018/05/31/macri-and-macronwhy-the-argentine-and-french-presidents-sharemore-than-their-surnames

Meguid, B. M. (2005). Competition between unequals: The role of mainstream party strategy in niche party success. American Political Science Review, 99(3), 347-359.

Mondon, A. (2017). Limiting democratic horizons to a nationalist reaction: Populism, the radical right and the working class. Javnost-The Public, 24(4), 355-374.

Mudde, C. (2004). The populist zeitgeist. Government and Opposition, 39(4), 542-563.

Mudde, C. (2007). Populist radical right parties in Europe. Cambridge: Cambridge University Press.

Mudde, C. (2010). The populist radical right: A pathological normalcy. West European Politics, 33(6), 1167-1186.

Mudde, C., \& Kaltwasser, C. R. (2017). Populism: A very short introduction. Oxford: Oxford University Press.

Müller, J.-W. (2016). What is populism? Philadelphia, PA: University of Pennsylvania Press.

Norris, P., \& Inglehart, R. (2019). Cultural backlash: Trump, Brexit, and authoritarian populism. New York, NY: Cambridge University Press.

Oesch, D. (2008). Explaining workers' support for rightwing populist parties in Western Europe: Evidence from Austria, Belgium, France, Norway, and Switzerland. International Political Science Review/Revue Internationale de Science Politique, 29(3), 349-373.

Panizza, F. (2005). Populism and the mirror of democracy. London: Verso.

Pauwels, T. (2014). Populism in Western Europe: Comparing Belgium, Germany and the Netherlands. Abingdon: Routledge.

Pehe, J. (2018). Explaining Eastern Europe: Czech democracy under pressure. Journal of Democracy, 29(3), 65-77.

Perottino, M., \& Guasti, P. (2020). Technocratic populism à la française? The roots and mechanisms of Emmanuel Macron's success. Politics and Governance, 8(4), 545-555.

Petrova, T., \& Snegovaya, M. (2020). Explaining the rise of illiberal populism in Central Europe. Unpublished manuscript.

Ramiro, L. (2016). Support for radical left parties in West- 
ern Europe: Social background, ideology and political orientations. European Political Science Review, 8(1), 1-23.

Rooduijn, M. (2018). What unites the voter bases of populist parties? Comparing the electorates of 15 populist parties. European Political Science Review, 10(3), 351-368.

Santana, A., Zagórski, P., \& Rama, J. (2020). At odds with Europe: Explaining populist radical right voting in Central and Eastern Europe. East European Politics, 36(2), 288-309.

Schedler, A. (1996). Anti-political establishment parties. Party Politics, 2(3), 291-312.

Schmitt-Beck, R. (2017). The 'Alternative Für Deutschland in the electorate': Between single-issue and right-wing populist party. German Politics, 26(1), 124-148.

Shehaj, A., Shin, A. J., \& Inglehart, R. (2019). Immigration and right-wing populism: An origin story. Party Politics. Advance online publication. https://doi.org/ $10.1177 / 1354068819849888$

Siri, J. (2018). The Alternative for Germany after the 2017 election. German Politics, 27(1), 141-145.

Snegovaya, M. (2020). How the post-communist left reformed and lost. Unpublished manuscript.

Spies, D. (2013). Explaining working-class support for extreme right parties: A party competition approach. Acta Politica, 48(3), 296-325.

Stockemer, D. (2017). The Front National in France: Continuity and change under Jean-Marie Le Pen and Marine Le Pen. Ontario: Springer.

Stockemer, D., \& Barisione, M. (2017). The 'new' dis- course of the Front National under Marine Le Pen: A slight change with a big impact. European Journal of Communication, 32(2), 100-115.

Taggart, P. (2000). Populism. Buckingham: Open University Press.

Taggart, P. (2004). Populism and representative politics in contemporary Europe. Journal of Political Ideologies, 9, 269-288.

Úsvit prrímé demokracie. (2013). Program hnutí [Program of the movement]. Úsvit prímé demokracie. Retrieved from https://web.archive.org/web/ 20131016112400/http://www.hnutiusvit.cz/ program-hnuti

Vachudova, M. A. (2020). Ethnopopulism and democratic backsliding in Central Europe, East European Politics, 36(3), 318-340.

Visser, M., Lubbers, M., Kraaykamp, G., \& Jaspers, E. (2014). Support for radical left ideologies in Europe. European Journal of Political Research, 53(3), 541-558.

Werts, H., Scheepers, P., \& Lubbers, M. (2013). Euroscepticism and radical right-wing voting in Europe, 2002-2008: Social cleavages, socio-political attitudes and contextual characteristics determining voting for the radical right. European Union Politics, 14(2), 183-205.

Zulianello, M. (2020). Varieties of populist parties and party systems in Europe: From state-of-the-art to the application of a novel classification scheme to 66 parties in 33 countries. Government and Opposition, 55(2), 327-347.

\section{About the Author}

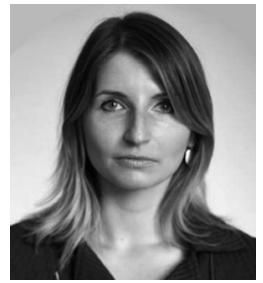

Maria Snegovaya (PhD) is a Visiting Scholar at George Washington University, and a Postdoctoral Scholar at the PPE program at Virginia Tech. She is a comparative politics, international relations, and statistical methods specialist. The key focus of her research is democratic backsliding in Central and Eastern Europe, as well as Russia's domestic and foreign policy. Her research results and analysis have appeared in policy and peer-reviewed journals, including Journal of Democracy, Democratization, and Post-Soviet Affairs. Her research has been referenced in publications such as the New York Times, Bloomberg, the Economist, and Foreign Policy. She is frequently invited to give talks at U.S. universities and think tanks. 